Article

\title{
Conserved G-Quadruplexes Regulate the Immediate Early Promoters of Human Alphaherpesviruses
}

\author{
Ilaria Frasson $\mathbb{D}$, Matteo Nadai $\mathbb{D}$ and Sara N. Richter * $\mathbb{D}$ \\ Department of Molecular Medicine, University of Padua, via A. Gabelli 63, 35121 Padua, Italy \\ * Correspondence: sara.richter@unipd.it; Tel.: +39-0498272346
}

Received: 31 May 2019; Accepted: 26 June 2019; Published: 27 June 2019

check for updates

\begin{abstract}
Human Alphaherpesviruses comprise three members, herpes simplex virus (HSV) 1 and 2 and varicella zoster virus (VZV). These viruses are characterized by a lytic cycle in epithelial cells and latency in the nervous system, with lifelong infections that may periodically reactivate and lead to serious complications, especially in immunocompromised patients. The mechanisms that regulate viral transcription have not been fully elucidated, but the master role of the immediate early (IE) genes has been established. G-quadruplexes are non-canonical nucleic-acid structures that control transcription, replication, and recombination in many organisms including viruses and that represent attractive antiviral targets. In this work, we investigate the presence, conservation, folding and activity of G-quadruplexes in the IE promoters of the Alphaherpesviruses. Our analysis shows that all IE promoters in the genome of HSV-1, HSV-2 and VZV contain fully conserved G-quadruplex forming sequences. These comprise sequences with long loops and bulges, and thus deviating from the classic G-quadruplex motifs. Moreover, their location is both on the leading and lagging strand and in some instances they contain exuberant G-tracts. Biophysical and biological analysis proved that all sequences actually fold into G-quadruplex under physiological conditions and can be further stabilized by the G-quadruplex ligand BRACO-19, with subsequent impairment of viral IE gene transcription in cells. These results help shed light on the control of viral transcription and indicate new viral targets to design drugs that impair the early steps of Alphaherpesviruses. In addition, they validate the significance of G-quadruplexes in the general regulation of viral cycles.
\end{abstract}

Keywords: G-quadruplex; immediate early promoters; Alphaherpesvirinae; Herpesvirus; virus

\section{Introduction}

In the last years the fact that the DNA can adopt complex secondary structures other than the double-stranded (ds) form wrapped around histones and packaged as chromatin [1] has become evident [2-4]. Guanine (G)-rich sequences in nucleic acids can assemble into G-quadruplex (G4) structures, comprising G-tetrads linked by loop nucleotides. Each G-tetrad is composed of four G residues connected through Hoogsteen-type hydrogen bonds. G4s are highly polymorphic structures, the topology of which depends on the strand stoichiometry and polarity, the nature and length of the loops and their location in the sequence [5]. The G4 parallel, antiparallel or mixed topology is directly correlated to the syn and anti conformational state of the glycosidic bond between the G base and the sugar [2]. The anti conformation characterizes a parallel folding, while antiparallel G4s can adopt both syn and anti orientations [6]. A number of different experimental techniques are used to study G-quadruplex formation, each examining different aspects of the structures, and hence reporting on different aspects of their formation. Circular Dichroism (CD) is a sensitive tool, widely used to investigate the conformations of nucleic acids. Based on the CD profile of maximum and minimum peaks at signature wavelengths (around 240, 260 and $290 \mathrm{~nm}$ ), this technique allows identification of the G4 folding and characterization of the G4 topology [7]. UV absorption is an 
additional useful technique: G4s show both a hypochromic and a hyperchromic sigmoid transition at 295 and $240 \mathrm{~nm}$, respectively [8]. The Thermal Difference Spectra (TDS) acquired by subtracting the UV absorbance spectra of the unfolded from the folded form of a given sample yield profiles that are characteristic of the G4 (i.e., a negative peak around $295 \mathrm{~nm}$, and two positive peaks around 275 and $243 \mathrm{~nm}$ ). Other useful techniques to highlight G4 formation are Taq polymerase stop assay [9] and mass spectrometry [10,11]. Finally, to acquire the structural details of G4 folding at the atomic level, NMR and X-ray crystallography are the ideal techniques, recently reported also in cells $[6,12,13]$.

G4s have been shown to regulate key cellular processes, including gene expression and mRNA translation, many of which are in turn linked to significant human disorders [14-16]. The most recent literature has broadened the G4 spectrum of influence also to pathogens [17-23]. In the last years many viruses have been reported to have putative G4 sequences (PQS) in their genome, and in most cases the biological role of these structures and the potential administration of G4-ligands as active and selective antiviral agents have been described [24]. Interestingly, G4s and PQS that are significant from a functional standpoint have been repeatedly identified in members of the Herpesviridae virus family both at the genomic and mRNA level [17-19,25-27]. This family contains over 100 ds-DNA viruses that infect humans and a wide range of eukaryotic organisms, with eight members that are exclusively human pathogens [28]. These viruses differ significantly with respect to base composition and sequence arrangement of their DNA, but share many biologic properties including the ability to remain latent in their host. On the basis of these, the human non-zoonotic Herpesviruses have been classified into three subfamilies, i.e., Alphaherpesvirinae, Betaherpesvirinae and Gammaherpesvirinae. The members of the Alphaherpesvirinae subfamily are characterized by a short reproductive cycle, rapid spread in culture, efficient killing of infected cells, and capacity to establish latent infections primarily but not exclusively in sensory ganglia. This subfamily contains the genera Simplexvirus (HSV-1, HSV-2) and Varicellovirus (VZV). The life cycle of these genera is characterized by a coordinated and sequential cascade of expression of three temporal classes of viral genes [29,30]: the viral tegument protein VP16 binds to the TAATGARAT signal sequence and activates transcription of the immediate early (IE) viral genes [31], the products of which in turn activate transcription of the early and late viral genes; transcription of the late viral genes is also coupled to viral DNA replication. IE gene products include regulatory proteins, while early and late gene products comprise the viral replication machinery and the structural components of the virus, respectively.

We have recently demonstrated and visualized the presence of G4s in the HSV-1 genome [27] and their targeting by two classes of G4-ligands, which efficiently inhibited viral replication [17,32]. In addition, we evidenced that several members of the Herpesviridae family, i.e., HSV-1, HSV-2, VZV, HHV-4 and HHV-8, are statistically significantly enriched in G4 patterns [33]. These data suggest a conserved and essential role of G4s in Herpesviruses.

Here we show that conserved and stable G4s are present in crucial points of the Alphaherpesvirinae (i.e., HSV-1, HSV-2 and VZV) genome, in particular in promoters of IE genes, the major regulators of the life cycle of these viruses. The IE promoters contain multiple G4s on both leading and lagging strands; these viral G4s are in general stable and can be further stabilized by G4-ligands. Their folding results in inhibition of transcription. A significant parallelism in conserved G4s in key genomic regulatory regions within members of the same viral subfamily becomes apparent. Our results point for the first time to a G4-mediated regulation of the initial viral steps of this important class of human pathogens and may pave the way to a deeper understanding of Alphaherpesvirinae infection regulation.

\section{Results}

\subsection{Detection of PQS in Herpesviridae Immediate Early (IE) Promoters}

G4s have been reported to regulate transcription, both at the cellular and viral level, when embedded in promoter regions $[15,24]$. The HSV-1 infective cycle is predominately driven by the five immediate early (IE) genes, namely ICP0, ICP4, ICP27 (UL54), ICP22 and ICP47 (US12) [34]. Our 
previous investigation showed that the GGG-island type PQS in HSV-1 were distributed along four defined genomic features, i.e., coding sequences (CDS), repeat regions (RR), $5^{\prime}$ - and $3^{\prime}$-untranslated (UTR), and promoter regions, with a particularly high concentration in the RR and $5^{\prime}$-regulatory region [33]. However, while CDS and RR are explicitly described in RefSeq and GenBank databases, the annotation for promoters in viruses is generally inconsistent. To check whether G4s were reliably present in the promoters of HSV-1 IE genes, we first selected the region up to $1 \mathrm{~kb}$ upstream of the Transcription Start Site (TSS) of any unambiguous IE transcripts in the HSV-1 reference genome (NC_001806.2) [35]. The selected regions were examined for the presence of specific genomic features, such as the TAATGARAT signals, TATA boxes, replication origins, polyA signals or CDSs on the opposite strand, in order to restrict our analysis to sequences that most likely contained promoters. This analysis yielded five prominent sequences.

To corroborate our findings, we looked for any reported biological evidence: interestingly, all five regions were indicated to exert promoter activity in IE genes [36-40], with the peculiarity that the same sequence repeated in two different genomic regions constitutes the promoter of the ICP22 and ICP47 genes [37]. We thus checked these four promoter regions for PQS by running an initial algorithm-driven analysis to search for $[\mathrm{G}(2) \mathrm{L}(1-7)] 4,[\mathrm{G}(3) \mathrm{L}(1-12)] 4$ and $[\mathrm{G}(4) \mathrm{L}(1-12)] 4$-type $\mathrm{G} 4 \mathrm{~s}$, followed by a manual sequence revision to highlight the possible presence of "non-canonical" G4s (i.e., G(3)L(0-12)) or bulged PQS [41]. Subsequently the degree of conservation of each sequence was retrieved from the G4 virus website (http://www.medcomp.medicina.unipd.it/main_site/doku.php?id=g4virus\#data_download) in order to discard non-conserved regions. Interestingly, all identified PQS were fully conserved, both in terms of G-tracts and loop-length and -composition, in the entire set of fully sequenced genomes present in the National Center for Biotechnology Information (NCBI) databank. The HSV-1 IE promoters contained multiple PQS (Table 1), embedded both in the leading and lagging strand.

Table 1. Putative Quadruplex Sequences (PQS) in the Herpes Simplex Virus 1 (HSV-1) Immediate Early (IE) promoter sequences. Each PQS is indicated by the $5^{\prime}$ nucleotide (nt) position on the viral reference genome (NC_001806.2). The leading and the lagging strands are indicated with respect to the Transcription Start Site (TSS) position. The conservation ratio (C (\%)) of the entire sequence (G tracts and loops) among all the strains available in the National Center for Biotechnology Information (NCBI) databank is also indicated.

\begin{tabular}{|c|c|c|c|}
\hline HSV-1 & Leading Strand & Lagging Strand & C (\%) \\
\hline \multicolumn{4}{|l|}{ ICPO } \\
\hline 1875 & $\begin{array}{l}\text { GCGGGAGGGGCATGCTA } \\
\text { ATGGGGTTCTTTGGGG }\end{array}$ & & 100 \\
\hline 1881 & $\begin{array}{l}\text { GGGGCATGCTAATGGGGT } \\
\text { TCTTTGGGGGACACCGGG }\end{array}$ & & 100 \\
\hline 1966 & $\begin{array}{l}\text { GGGGGCGCCGGGTTG } \\
\text { GTCCCCGGGGACGGGG }\end{array}$ & & 100 \\
\hline 2009 & $\begin{array}{l}\text { GGGCCTGCCTCCCCTGGG } \\
\text { ACGCGCGGCCATTGGGGG }\end{array}$ & & 100 \\
\hline 2066 & GGGGAGGGGAAAGGCGTGGGG & & 100 \\
\hline \multicolumn{4}{|l|}{ ICP4 } \\
\hline R146532 & & $\begin{array}{l}\text { GGGCGGGGCGCG } \\
\text { AGGGCGGGTGGG }\end{array}$ & 100 \\
\hline 146574 & $\begin{array}{l}\text { GGGCGGGGCCGGG } \\
\text { GGTTCGACCAACGGG }\end{array}$ & & 100 \\
\hline 146578 & $\begin{array}{c}\text { GGGGCCGGGGGTTCGAC } \\
\text { CAACGGGCCGCGGCCACGGG }\end{array}$ & & 100 \\
\hline 146666 & $\begin{array}{l}\text { GGGGTGGGCCCGCC } \\
\text { GGGGGGGCGGGGGG }\end{array}$ & & 100 \\
\hline 146947 & $\begin{array}{l}\text { GGGGCCGGGGGTTCGACCA } \\
\text { ACGGGCCGCGGCCACGGG }\end{array}$ & & 100 \\
\hline
\end{tabular}


Table 1. Cont.

\begin{tabular}{|c|c|c|c|}
\hline HSV-1 & Leading Strand & Lagging Strand & $\mathrm{C}(\%)$ \\
\hline \multicolumn{4}{|c|}{ ICP22/ICP47 } \\
\hline 131746 & GGGCAGGGGGC GGGGCCCGGG & \multirow{6}{*}{$\begin{array}{l}\text { GGGCGGGACCGGGGGGCCCGGG } \\
\text { GACGGCCAACGGGCGCGCGGGG }\end{array}$} & 100 \\
\hline R131803 & & & 100 \\
\hline 131857 & $\begin{array}{l}\text { GGGACCAACGGGACG } \\
\text { GCGGGCGGCCCAAGGG }\end{array}$ & & 100 \\
\hline 132059 & $\begin{array}{l}\text { GGGGGCGGGCCCGGGCGGC } \\
\text { GGGGGGCGGGTCTCTCCGGCG }\end{array}$ & & 100 \\
\hline 132065 & GGGCCCGGGCG GCGGGGGGCGGG & & 100 \\
\hline 132070 & $\begin{array}{l}\text { GGGCGGCGGGGGG } \\
\text { CGGGTCTCTCCGGCG }\end{array}$ & & 100 \\
\hline R132290 & & \multirow[t]{3}{*}{ GGGTGGGGTGGGCGGG } & 100 \\
\hline 132411 & $\begin{array}{l}\text { GGGGGCGGAGGAGGGGGGAC } \\
\text { GCGGGGGCGGAGGAGGGGG }\end{array}$ & & 100 \\
\hline 132424 & $\begin{array}{l}\text { GGGGGGACGCGGGGGCGGAG } \\
\text { GAGGGGGGACGCGGGGG }\end{array}$ & & 100 \\
\hline \multicolumn{4}{|l|}{ ICP27 } \\
\hline 113501 & $\begin{array}{l}\text { GGGGCGGGGGCCCC } \\
\text { GCCCGGGGGGCGG }\end{array}$ & & 100 \\
\hline 113519 & $\begin{array}{l}\text { GGGGGGCGGAACGA } \\
\text { GGAGGGGTTTGGG }\end{array}$ & & 100 \\
\hline
\end{tabular}

ICP0 displayed five PQSs, two preceding the TAATGARAT signal, and three upstream the TATA box, all on the leading strand (Figure 1A); ICP4 promoter contained five PQSs, four embedded in the region encompassing the TAATGARAT signal and the TATA box, the most distal G4 being on the lagging strand, and one close to the TSS (Figure 1B); ICP22/ICP47 promoter included 9 PQSs, 6 upstream of the TATA box signal, both on the leading and lagging strand and the remaining 3 between the TATA box and the TSS (Figure 1C); ICP27 promoter displayed two partially overlapped PQSs embedded between the TAATGARAT signal and the TATA box (Figure 1D). Notably, ICP0 and ICP22/ICP47 promoters contained bulged PQS. Moreover, the majority of the predicted PQS had at least one region possibly forming GC stem loops.

To check whether the G4 pattern identified in the HSV-1 IE promoters was also present and conserved in all members of the Alphaherpesviruses, we extended our analysis to HSV-2 and VZV IE gene promoters. First of all, we identified the homologues genes in the three viruses (Table 2) [42,43] and then performed the same algorithm and manual predictive analysis described for HSV-1.

Table 2. IE genes/proteins (they maintain the same name) in the three Alphaherpesviruses. The proteins of each single virus can complement the relative homologue of the other two classes. The only exception is Varicella Zoster Virus-Open Reading Frame 4 (VZV-ORF4), which cannot entirely substitute for HSV-1/HSV-2 ICP27 protein.

\begin{tabular}{cccc}
\hline & HSV-1 & HSV-2 & VZV \\
\hline \multirow{4}{*}{ IE genes/proteins } & ICP0 & ICP0 & ORF61 \\
& ICP4 & ICP4 & ORF62 \\
& ICP27 & ICP27 & ORF4 \\
& ICP47 & ICP47 & n.p. \\
& ICP22 & ICP22 & ORF63 \\
\hline
\end{tabular}


A.
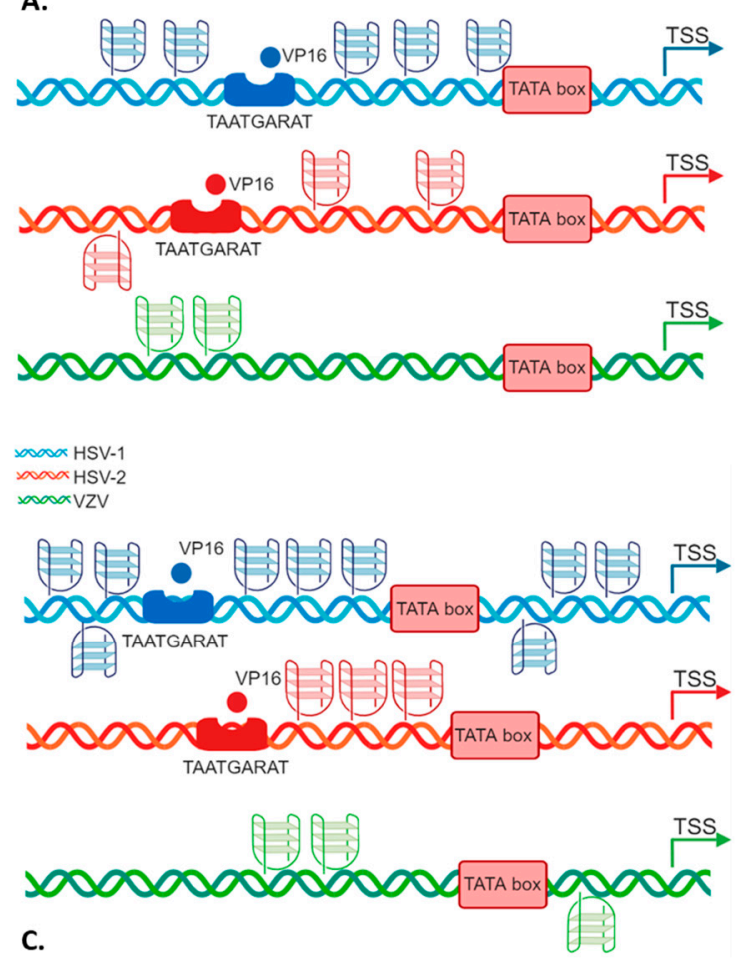

B.
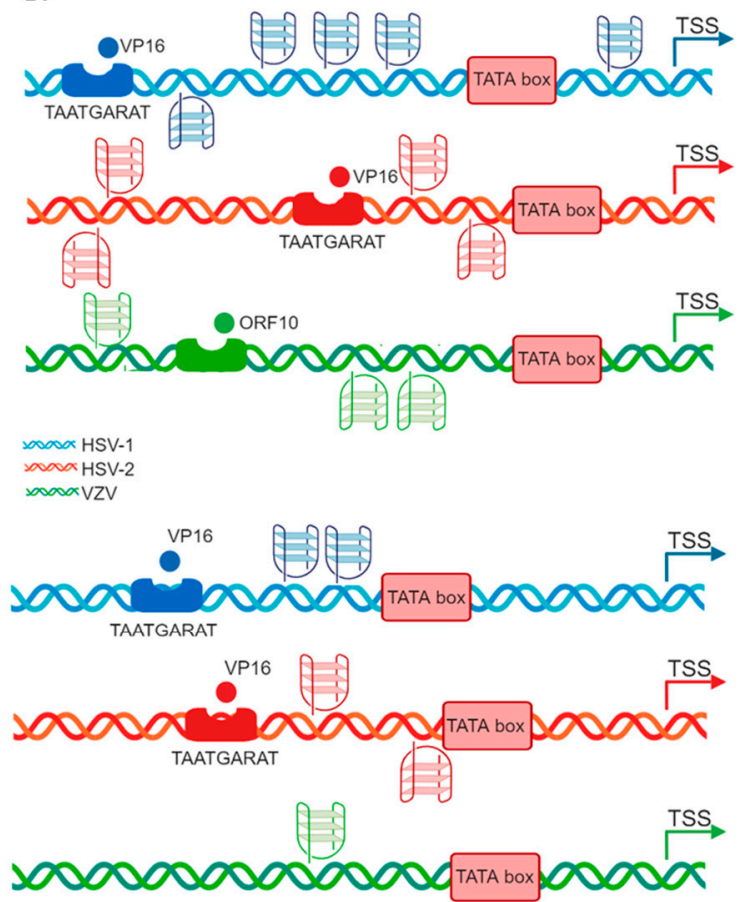

D.

Figure 1. Schematic comparative representation of G4s in Alphaherpesvirus IE promoters. The four IE promoters (A. ICP0; B. ICP4 or ORF62; C. ICP22/ICP47 or ORF63 and D. ICP27) are reported. HSV-1, HSV-2 and VZV promoter schemes are shown in blue, red and green, respectively. The TAATGARAT region is shown as a blue/red box with the VP16 protein nearby (or as a green box with ORF10 protein in the case of VZV); the TATA box is represented as a red box; the arrow indicates the position of the Transcriptional Start Site (TSS). The position of each of these features on the double helix with respect to the TSS is on scale. In each promoter, the predicted G4s are shown above and below the DNA strand for G4s present in the leading and lagging strand, respectively.

Notably, also HSV-2 and VZV presented fully conserved PQS within the IE promoters, as reported in Table 3.

HSV-2, has always been considered a close homologue of HSV-1, but recent research highlighted that the two viruses are less related than initially believed [44]. Our analysis retrieved fewer PQS in the HSV-2 IE promoter regions with respect to HSV-1, but all of them were conserved in all sequenced circulating strains. VZV, despite sharing a similar biology with HSV-1 and HSV-2, including latency in sensory neurons, has a different genome organization and gene expression regulation $[45,46]$. The number of PQS predicted for VZV promoters was the smallest among the three viruses $(n=6)$; however, all of them retained the highest degree of conservation. PQS were retrieved on both strands: similarly to HSV-1 ICP22 and ICP47, ORF62 and ORF63 of VZV are transcribed in opposite directions from a $1.5-\mathrm{kb}$ intergenic region that acts as a bidirectional promoter [44] and also contains the VZV origin of replication [47]. ORF62 and ORF63 TSSs lie on opposite strands, thus PQS on the leading strand with respect to ORF63, on the lagging strand may act as regulators of ORF62, and vice versa. VZV is also the only virus with a predicted GG-island type PQS (ORF4 4278). Even if the TAATGARAT sequence is not present in VZV promoters, a TAATGARAT-VP16-like transcriptional enhancement can be mimicked by the ORF10 protein [48]. The ORF10 protein has been shown to influence the transcription of the VZV immediate-early (IE) gene, ORF62, but not of ORF61, ORF4 or ORF63 [49,50]. The relative comparison of PQS position on each Alphaherpesviruses IE promoter is reported in Figure 2. 
Table 3. PQS in the HSV-2 and VZV IE promoter sequences. Each PQS is indicated by the $5^{\prime}$ nt position on the viral reference genome (NC_001798.2 and NC_001348.1). The leading and the lagging strands are indicated with respect to the TSS position. The conservation ratio $(\mathrm{C}(\%))$ of the entire sequence $(\mathrm{G}$ tracts and loops) among all the strains available in the NCBI databank is also indicated.

\begin{tabular}{|c|c|c|c|}
\hline HSV-2 & Leading Strand & Lagging Strand & $\mathrm{C}(\%)$ \\
\hline \multicolumn{4}{|l|}{ ICPO } \\
\hline 1571 & & $\begin{array}{l}\text { GGGAAGCCGGCGCGGGGCG } \\
\text { GTCGCCGGGGCGGAGTCCGGG }\end{array}$ & 100 \\
\hline 1913 & $\begin{array}{l}\text { GGGGGCGGGCACCACTCAGGGCC } \\
\text { GCGCCGGCGGGGCGCCGGGGGG }\end{array}$ & & 100 \\
\hline 2027 & $\begin{array}{l}\text { GGGGACGGGGCCGC } \\
\text { CCCGAGAGGGGGGG }\end{array}$ & & 100 \\
\hline \multicolumn{4}{|l|}{ ICP4 } \\
\hline 149044 & & GGGGCGCGCGGGGCGGGGGG & 100 \\
\hline 149088 & $\begin{array}{l}\text { GGGGCCGGCGGGGG } \\
\text { CCAACGGGAGCGCGGGG }\end{array}$ & & 100 \\
\hline 149287 & $\begin{array}{l}\text { GCGGACGCGCGGG } \\
\text { CGTCGGGGCGGGG }\end{array}$ & & 100 \\
\hline 149570 & & GGGGCGGCAGTG GGGGGGGGTGG & 100 \\
\hline \multicolumn{4}{|c|}{ ICP22/ICP47 } \\
\hline 132299 & $\begin{array}{l}\text { GGGGGGCCGGGC } \\
\text { CGGGGGGACGGG }\end{array}$ & & 100 \\
\hline 132325 & $\begin{array}{l}\text { GGGGGGACGGGC } \\
\text { CGGGGGGACGGG }\end{array}$ & & 100 \\
\hline 132988 & GGGCCCGGACG GGGGGCGGG & & 100 \\
\hline \multicolumn{4}{|l|}{ ICP27 } \\
\hline 114386 & $\begin{array}{l}\text { GGGGACGGCGGGGGCGGGGG } \\
\text { CGGTGACGCCCGACGGGGAGGG }\end{array}$ & & 100 \\
\hline 114579 & & $\begin{array}{l}\text { GGGGCTGGGATGGCGG } \\
\text { GTGTCCTCCGAGGGGG }\end{array}$ & 100 \\
\hline VZV & Leading Strand & Lagging Strand & $\mathrm{C}(\%)$ \\
\hline \multicolumn{4}{|l|}{ ORF61 } \\
\hline 104021 & & $\begin{array}{l}\text { GGGGTCCGCCGGGCGCCCAGAAACC } \\
\text { GGGGGGGGGTTATTTTCGGGGGGGGG }\end{array}$ & 100 \\
\hline 105081 & GGGCGGGCGACGGGCGGG & & 100 \\
\hline \multicolumn{4}{|c|}{ ORF62/ORF63 } \\
\hline $\begin{array}{l}109246 \\
109703\end{array}$ & $\begin{array}{c}\text { GGGGAGGAAATATGCG } \\
\text { GTCGAGGGGGGGG } \\
\text { GCGGTTTTATGGGGT } \\
\text { GTGGGCGGG }\end{array}$ & & 99 \\
\hline 110410 & & $\begin{array}{l}\text { GGGTAAAATGGCAATGGGGGATT } \\
\text { CCGGGGCGGGAGACCTTCGATTGGG }\end{array}$ & 100 \\
\hline \multicolumn{4}{|l|}{ ORF4 } \\
\hline 4278 & $\begin{array}{l}\text { GGGTGCAGGTAA } \\
\text { GCTTGTTTGGGG }\end{array}$ & & 100 \\
\hline
\end{tabular}



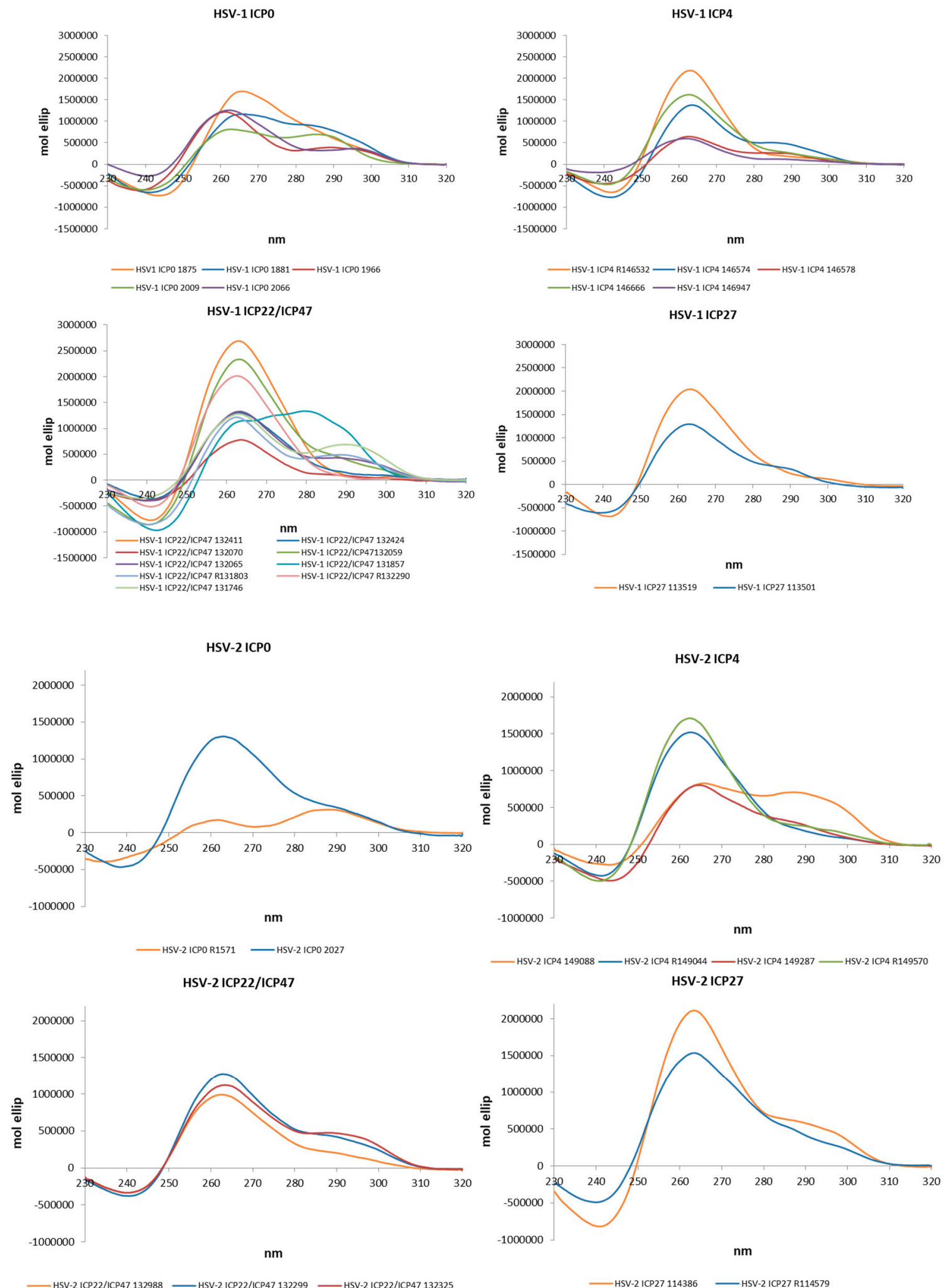

Figure 2. Cont. 


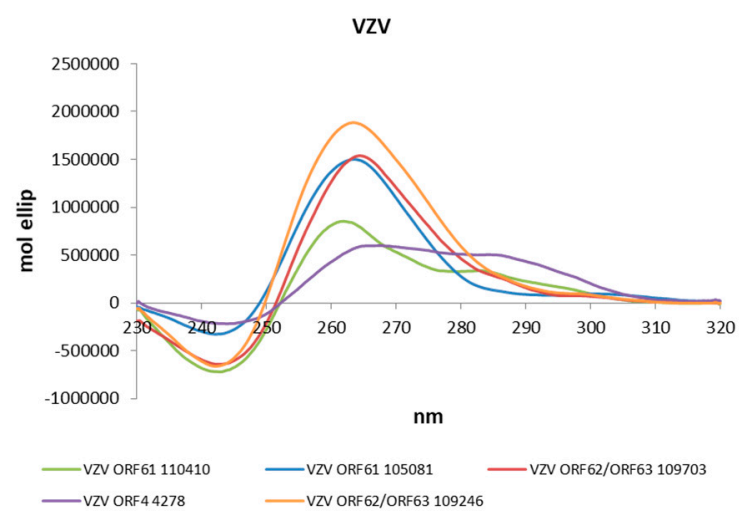

Figure 2. Circular Dichroism (CD) spectra of the PQS embedded in the Alphaherpesvirus IE promoters in $\mathrm{PB} 20 \mathrm{mM}$ and $\mathrm{KCl} 70 \mathrm{mM}$.

These data indicate the possibility that IE gene expression of Alphaherpesviruses is regulated by G4s.

\subsection{The Identified PQSs Fold into G4 Structures}

The actual ability of Alphaherpesvirus IE promoter PQSs to form G4 structures was initially assessed by Circular Dichroism (CD), as this technique is considered a reliable tool to study nucleic acids conformation [51]. All sequences were analysed in the presence of $\mathrm{K}^{+}$to establish $\mathrm{G} 4$ folding, topology and thermal stability. Table 4 and in Figure 2 show that all predicted PQS did actually fold into G4 structures. The large majority (77\%) of G4s displayed a parallel topology, with a maximum positive peak at $\sim 260 \mathrm{~nm}$ and a minimum at $\sim 240 \mathrm{~nm}$. Some G4s were also characterized by a modest shoulder at $295 \mathrm{~nm}$, without wavelength shift of the minimum peak at $240 \mathrm{~nm}$ and were considered parallel G4s (Table 4). The remaining sequences (18\%) showed two maxima at 265 and $295 \mathrm{~nm}$ and a minimum at $245 \mathrm{~nm}$ and were thus classified as hybrid structures.

Table 4. CD and Thermal Difference Spectra (TDS) analysis of PQS embedded in the Alphaherpesvirus IE promoters. Both analyses were performed at $100 \mathrm{mM} \mathrm{KCl}$. Topology and $\mathrm{T}_{\mathrm{m}}$ values in the presence and absence of B19 are reported. For mixed structures, $T_{m}$ values were calculated at both 260 and 290 nm. n.a.: oligonucleotide not available due to its too high $\mathrm{G}$ content.

\begin{tabular}{|c|c|c|c|c|c|}
\hline HSV-1 & Topology & $\mathrm{T}_{\mathrm{m}}$ & $T_{m}(B 19)$ & $\Delta \mathrm{T}_{\mathrm{m}}$ & TDS \\
\hline \multicolumn{6}{|l|}{ ICPO } \\
\hline 1875 & parallel & $60.9 \pm 0.1$ & $73.3 \pm 0.2$ & 12.4 & + \\
\hline 1881 & hybrid & $51.9 \pm 0.3 / 45.9 \pm 0.2$ & $80.7 \pm 1.2 / 66.3 \pm 0.5$ & $28.8 / 20.4$ & $+^{*}$ \\
\hline 1966 & parallel & $68.6 \pm 0.1$ & $>90$ & $>21.4$ & + \\
\hline 2009 & hybrid & $54.9 \pm 0.6 / 65.0 \pm 0.4$ & $69.2 \pm 0.6 />90$ & $14.3 />25$ & $+/-$ \\
\hline 2066 & parallel & $>90$ & & & + \\
\hline \multicolumn{6}{|l|}{ ICP4 } \\
\hline R146532 & parallel & $79.5 \pm 0.1$ & $>90$ & $>10.5$ & + \\
\hline 146574 & parallel & $63.4 \pm 0.2$ & $>90$ & $>26.6$ & + \\
\hline 146578 & parallel & $66.2 \pm 0.1$ & $80.3 \pm 0.4$ & 14.1 & $+/-$ \\
\hline 146666 & parallel & $>90$ & & & + \\
\hline 146947 & parallel & $69.2 \pm 0.2$ & $>90$ & $>20.8$ & + \\
\hline \multicolumn{6}{|c|}{ ICP22/ICP47 } \\
\hline 131746 & hybrid & $>90 / 71.4 \pm 0.8$ & & & + \\
\hline R131803 & hybrid & $73.7 \pm 0.8 / 76.7 \pm 0.9$ & $>90 / 85.1 \pm 0.8$ & $>16.3 / 8.4$ & $+*$ \\
\hline 131857 & hybrid & $62.4 \pm 0.5 / 65.3 \pm 0.2$ & $69.6 \pm 0.9 / 67.6 \pm 0.4$ & $7.2 / 2.3$ & $+^{*}$ \\
\hline 132059 & parallel & $>90$ & & & + \\
\hline 132065 & hybrid & $>90 / 78.8 \pm 0.7$ & & & + \\
\hline
\end{tabular}


Table 4. Cont.

\begin{tabular}{|c|c|c|c|c|c|}
\hline HSV-1 & Topology & $\mathrm{T}_{\mathrm{m}}$ & $\mathrm{T}_{\mathrm{m}}(\mathrm{B} 19)$ & $\Delta \mathrm{T}_{\mathrm{m}}$ & TDS \\
\hline 132070 & parallel & $74.2 \pm 0.1$ & $>90$ & $>15.8$ & $+*$ \\
\hline R132290 & parallel & $>90$ & & & $+* *$ \\
\hline 132411 & parallel & $>90$ & & & + \\
\hline 132424 & parallel & $>90$ & & & $+* *$ \\
\hline \multicolumn{6}{|l|}{ ICP27 } \\
\hline 113501 & parallel & $>90$ & & & $+/-$ \\
\hline 113519 & parallel & $>90$ & & & + \\
\hline \multicolumn{6}{|l|}{ HSV-2 } \\
\hline \multicolumn{6}{|l|}{ ICPO } \\
\hline 1571 & hybrid & $77.7 \pm 0.8 / 79.0 \pm 0.7$ & $>90 / 71.2 \pm 1.1$ & $>12.3 /-7.8$ & $+/-$ \\
\hline 1913 & n.a. & & & & \\
\hline 2027 & parallel & $>90$ & & & + \\
\hline \multicolumn{6}{|l|}{ ICP4 } \\
\hline 149044 & parallel & $>90$ & & & + \\
\hline 149088 & hybrid & $67.2 \pm 0.7 / 72.6 \pm 0.7$ & $64.5 \pm 0.9 />90$ & $-2.7 />17.4$ & + \\
\hline 149287 & parallel & $67.2 \pm 0.7$ & $84.1 \pm 2.2$ & 16.9 & + \\
\hline 149570 & parallel & $81.8 \pm 0.8$ & $>90$ & $>8.2$ & + \\
\hline \multicolumn{6}{|c|}{ ICP22/ICP47 } \\
\hline 132299 & parallel & $>90$ & & & + \\
\hline 132988 & parallel & $>90$ & & & + \\
\hline 132325 & parallel & $>90$ & & & + \\
\hline \multicolumn{6}{|l|}{ ICP27 } \\
\hline 114386 & parallel & $75.9 \pm 0.4$ & $>90$ & $>14.1$ & $+*$ \\
\hline 114579 & parallel & $66.8 \pm 0.9$ & $83.4 \pm 0.7$ & 16.6 & + \\
\hline \multicolumn{6}{|l|}{ VZV } \\
\hline \multicolumn{6}{|l|}{ ORF61 } \\
\hline 104021 & n.a. & & & & \\
\hline 105081 & parallel & $75.9 \pm 0.4$ & $>90$ & $>14.1$ & + \\
\hline \multicolumn{6}{|c|}{ ORF62/ORF63 } \\
\hline 109246 & parallel & $>90$ & & & + \\
\hline 109703 & parallel & $57.7 \pm 0.2$ & $84.7 \pm 0.5$ & 27.0 & + \\
\hline 110410 & parallel & $56.5 \pm 0.4$ & $85.2 \pm 0.8$ & 28.7 & $+/-$ \\
\hline \multicolumn{6}{|l|}{ ORF4 } \\
\hline 4278 & hybrid & $57.5 \pm 0.3 / 53.2 \pm 0.5$ & $79.2 \pm 0.9 / 82.0 \pm 0.9$ & $21.7 / 28.8$ & + \\
\hline
\end{tabular}

The stability of all G4s was assessed by melting experiments monitored by CD. The melting temperatures $\left(\mathrm{T}_{\mathrm{m}}\right)$ were calculated according to the van 't Hoff equation (Table 4 and Figure S1). In half of the analysed sequences (58\%) the CD signal decreased over temperature, leading to discrete $\mathrm{T}_{\mathrm{m}}$ values. Notably, the remaining sequences (42\%) maintained their $\mathrm{G} 4$ folding up to the maximum tested temperature $\left(90^{\circ} \mathrm{C}\right)$. For hybrid structures, where two transitions were visible, $\mathrm{T}_{\mathrm{m}}$ values were calculated at both wavelengths.

We next investigated the Alphaherpesvirus IE promoter sequences in the presence of the commercially available G4-ligand, BRACO-19 (B19), which has been reported to specifically recognize and stabilize G4 structures over double- and single-stranded nucleic acids [52]. The effect of B19 was assessed by CD thermal unfolding analysis. B19 was able to further stabilize all G4s, with an increase in $\mathrm{T}_{\mathrm{m}}$ higher than $10{ }^{\circ} \mathrm{C}$ (Table 4). In cases where several transitions were observed, $\mathrm{T}_{\mathrm{m}}$ values for each transition were annotated. The results obtained with B19 further confirm the ability of all the predicted sequences to fold into G4 structures. 
TDS spectra analysis was next employed to corroborate G4 folding. Mergny and others [8,53] established that G4 structures exhibit a TDS negative peak at $295 \mathrm{~nm}$, and two positive peaks at 275 and $243 \mathrm{~nm}$, respectively. The vast majority ( $86 \%$ ) of analysed sequences displayed the G4 distinctive TDS spectrum (Table 4 and Figure S1). Bulged sequences, sequences containing more than four G-islands and sequences retaining the ability to form stem-loops displayed the characteristic TDS at higher cation concentration $(\mathrm{KCl} 150 \mathrm{mM})$, which allowed increased stabilization of the $\mathrm{G} 4$ over possible competitor structures. Five sequences displayed only the two positive peaks, and thus reported a non-definite TDS spectrum (indicated as +/-). It is possible that "non canonical" G4 structures cannot confidently be distinguished by TDS analysis.

For these reasons, two non-canonical G4s were additionally explored by Taq polymerase stop assay. These corresponded to the HSV-1 ICP0 and ICP27 promoter sequences (ICPO 2066 and ICP27 113501+113519): the first one was a putative bulged G4 that displayed G4-representative CD and TDS profiles, the second with long G-tracts and the possibility to form GC stem loops, had showed an ambiguous TDS profile. The Taq polymerase stop assay indicates the ability of a G4 to block or pause the enzyme activity and allows evaluation of G4 structures within an extended DNA environment. Samples were incubated in the absence and presence of increasing concentrations of $\mathrm{KCl}$ (Figure 3), and $1 \mu \mathrm{M}$ B19. Stop sites resulted specific and located mainly at, or just before, the most $3^{\prime}$ G-tract involved in G4 formation (Figure 3, * symbol). Additional stop sites (Figure 3, a, §, \#, ¥ and \& symbols) corresponding to other G-tracts indicated the "breathing" of the G4 structure and possibly the ability of the tested oligonucleotides to fold into multiple G4 structures, preferentially stabilized at different $\mathrm{K}^{+}$concentrations. The G4-ligand B19 blocked enzyme processing mainly in correspondence of the most $3^{\prime}$ tract involved in G4 formation, suggesting that the structure with the longest sequence is likely the most stable and thus the one preferentially bound by B19 (Figure $3,{ }^{*}$ symbol). These data indicate that both the tested non-canonical G4s are able to fold into G4, and thus provide evidence that the TDS assay may lack the negative peak at $295 \mathrm{~nm}$ while still depicting a non-canonical G4.

Taken together these data indicate that IE PQS can fold into dynamic G4 structures, which are induced and stabilized by increasing concentrations of $\mathrm{K}^{+}$and a G4-ligand.

\subsection{G4s Tune IE Promoter Activity at the Cellular Level}

The biological role of G4s at the promoter level is still matter of debate since little is known on how G4 structures and their interaction with transcription factors and other proteins may contribute to regulate viral promoters. Here, we decided to study the activity of two representative promoters, i.e., HSV-1 ICP0 and ICP27 in cells. These two promoters were chosen both for their peculiar G4 content and for their unique roles during HSV-1 infection. ICP0 is the viral ubiquitin ligase that has been described to act as a powerful viral transactivator-both during productive infection and in reactivation from latency [54]. In contrast, at the nuclear level ICP27 induces the expression of a restricted number of early and late genes, such as UL42 (polymerase processivity factor) and UL44 (glycoprotein C) but it remains highly expressed during the whole viral life cycle [55]. The two sequences, ICP0 and ICP27 (NC_001806.2 nts 1551-2261 and nts 113451-113734, respectively) were cloned upstream of the firefly luciferase gene in a promoterless plasmid. The two promoters were studied in U-2 OS cells, a human osteosarcoma cell line that withstands HSV-1 infection [56], in the absence and presence of increasing concentrations of B19. The assay was performed monitoring also cell viability in the presence of B19 $\left(\mathrm{CC}_{50} \mathrm{U} 2-\mathrm{OS}>100 \mu \mathrm{M}\right)$ to avoid luciferase signal variation due to cytotoxicity. As shown in Figure 4, the activity of both promoters decreased in a dose dependent manner, up to $\sim 65 \%$ of the untreated control in ICP0 and up to $\sim 55 \%$ in ICP27, proving that in this case G4s act as suppressors of transcription. 


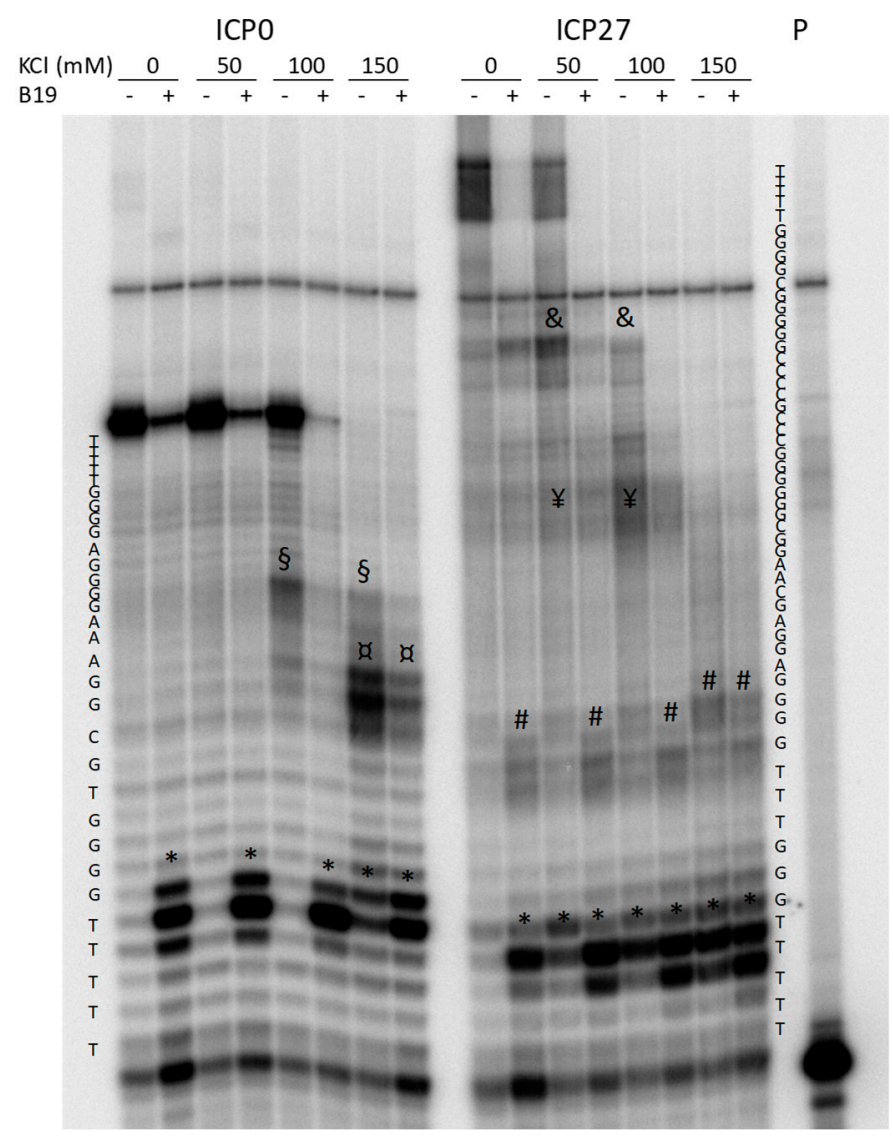

Figure 3. Sequencing PAGE of Taq-amplified ICP0 and ICP27 templates in the absence or presence of increasing concentrations of $\mathrm{KCl}$ and the G4-ligand B19. Symbols *, a, §, \#, ¥ and \& indicate pausing sites just before the G4 regions in the templates. $P$ indicates the lane of the labeled primer.

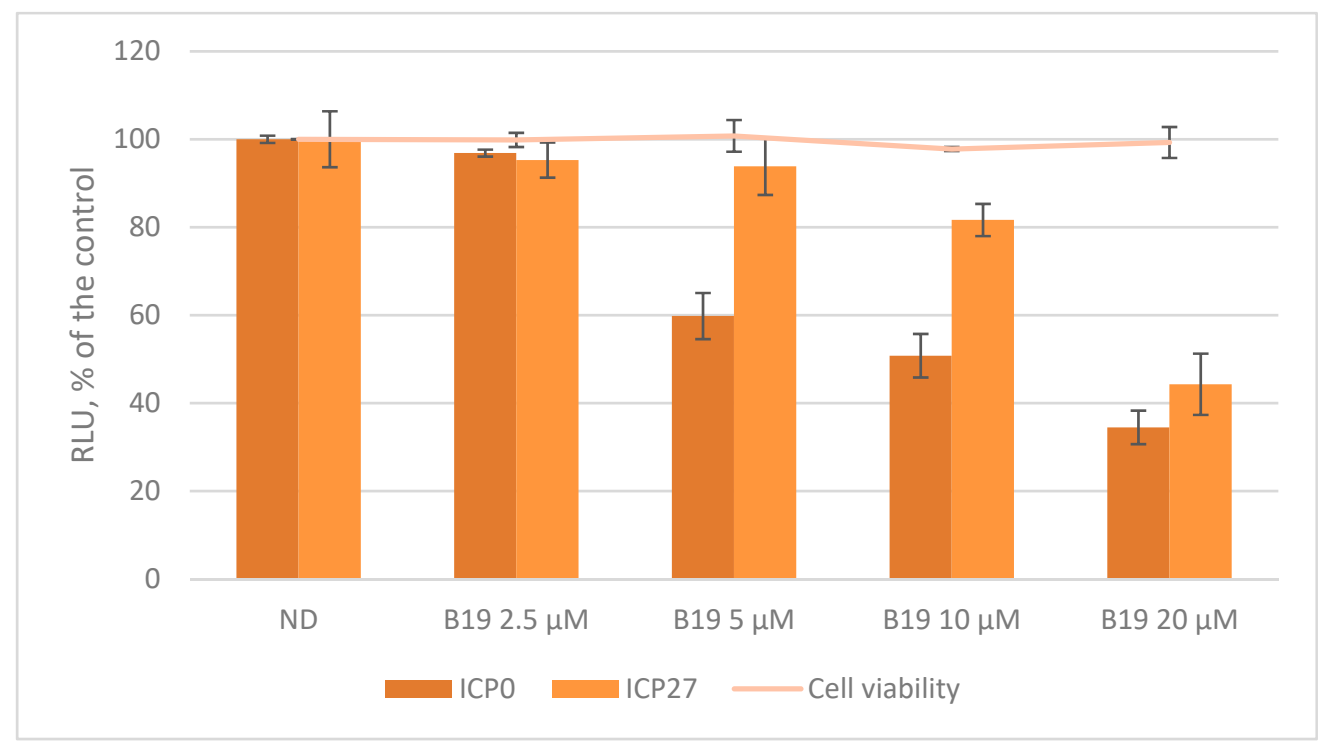

Figure 4. Luciferase assay on HSV-1 ICP0 and ICP27 promoters in U-2 OS (human osteosarcoma) cells in the presence of the G4 ligand B19 $(2.5-20 \mu \mathrm{M})$. Cell viability, determined by MTT (3-(4,5-dimethylthiazolyl-2)-2,5-diphenyltetrazolium bromide) assay, in the presence of B19 is also indicated. 
These findings support the hypothesis that G4s tune the activity of Alphaherpesvirus IE promoters, as indicated by the B19-mediated G4 stabilization, which down-regulates ICP0 and ICP27 transcription.

\section{Discussion}

In the past few years, interest in the characterization of G4 structures and their role within viral genomes has greatly increased, providing possibly innovative antiviral targets against many human pathogens. In this context, our group proved that HIV-1 transcription is modulated by the tuned folding/unfolding of G4s located in the U3 region of the LTR promoter [23,57]. We successively demonstrated that the HSV-1 genome contains an impressively high number of putative G4s that were visualized during infection in cells by means of an anti-G4 antibody [17,27]. In support of the presence and involvement of G4s in key viral processes, we found that two G4-ligands (B19 and a core extended naphthalene diimide) displayed remarkable antiviral activity in both viruses $[17,32,58,59]$.

The HSV-1 cycle is strictly regulated by five IE proteins (namely ICP0, ICP4, ICP22, ICP27 and ICP47), that are also responsible in vivo for the establishment of latency at the neuronal level $[34,60]$. The five genes that encode for these proteins are immediately transcribed after infection and mutations altering their expression are strongly associated with a dysregulated viral cycle [60].

In this work, we investigated the presence of G4s within the promoter regions of IE genes of all members of the Alphaherpesvirus subfamily. The promoters were unambiguously identified based both on the presence of characterizing motifs, such as the TATA box and the TAATGARAT sequence and on previously reported biological evidence. In each promoter, we found several multiple and non-overlapping G4 folding motifs, interestingly located both on the leading and lagging strands. At the promoter level, G4 structures on the lagging strand have been shown so far only in few examples, in particular in the promoter region of the REarranged during Transfection (RET) proto-oncogene [61,62] and as regulators of DNA strand replication [63] in mammalian cells. In the human papillomavirus as well as in the human cytomegalovirus, G4s on the lagging strand were predicted only in non-coding regulatory regions, lacking experimentally proved promoter activity $[18,64]$. Promoters containing multiple G4s have been described in oncogenes [65-67], however, none of these features has been reported in viruses as yet. This work indicates the possibility that the large and strictly regulated genome of Herpesviruses controls gene transcription at the promoter level through G4-mediated mechanisms, as reported for the human genome. ICP4 is the major viral transcription factor, and its promoter presents $5 \mathrm{G} 4 \mathrm{~s}$. The G4 most distant from the TSS is embedded in the lagging strand close to the TAATGARAT sequence, which is a recognition signal for the viral protein VP16 [31]: it is possible that this G4 is involved in the transactivation activity of VP16. The ICP22 and ICP47 promoters, which share the same sequence albeit in two different locations along the genome, display a high number of G4s, also in this case located on both strands: we envisage the possibility of a control on both transcription and replication, since in the same region resides oriS, one of the origins of viral genome replication [68]. ICP0 plays a major role both on viral transactivation during the lytic cycle and in reactivation from latency: it contains five G4s nearby the TAATGARAT sequence and TATA box. ICP27 is an essential HSV-1 IE protein along with ICP4, but in contrast to the latter which is expressed only in the early stages and is involved in transcription initiation, ICP27 is a multifunctional protein and its expression remains high throughout the viral cycle, with post-translational modifications that regulate its activity [69-71]. The ICP27 promoter is the one that contains fewer G4s. Four out of five ICP0 G4s, displaying low $\operatorname{Tm}\left(50<\operatorname{Tm}<68^{\circ} \mathrm{C}\right)$, were significantly stabilized by the G4-ligand, whereas ICP27 G4s were very stable even in the absence of B19 and thus were less affected by the G4-ligand. These features are likely the reason why we observed a lower degree of response to the G4-ligand B19 in cells for ICP27 compared to ICPO.

As HSV-1, HSV-2 and VZV are closely related viruses, all displaying a wide host-cell range, similar pathogenesis and analogous genome organization, we evaluated the presence of G4s also in HSV-2 and VZV IE promoters. The vast majority of the retrieved sequences, besides being fully conserved within all sequenced strains, were experimentally proven by at least two techniques to fold into G4 structures. 
Finally, we found that many of the Alphaherpesvirus IE promoter G4-forming sequences described in this work formed "non-canonical" G4s: they were able to fold even in the absence of loops (i.e., HSV-1 ICP4 149570; VZV ORF62/63 109246) or in the presence of putative stem-forming sequences in the loop (i.e., HSV-1 ICP0 1966; HSV-1 ICP4 146666, 146578 and 146947; HSV-1 ICP22/ICP47 R131803, 131857, 132059) or with bulges (i.e., HSV-1 ICP0 2009 and 2066; HSV-2 ICP4 149044, 149287). This fact indicates that the classic prediction methods based on motif recognition may overlook many non-canonical G4s that actually form. In this view, the newest machine learning models trained with sequences of experimentally validated G4 may yield more reliable results [72]. Moreover, several G4s (see HSV-1 ICP4, HSV-1 ICP22/ICP47, HSV-2 ICP0, HSV-2 ICP27 and VZV ORF62/ORF63) presented 5 G-tracts; multiple G-tracts have been previously described for another strictly regulated viral promoter, the LTR sequence of HIV-1 virus [23]. These data may corroborate the recently proposed hypothesis by Burrows CJ and co-workers that the tracts exceeding four work as "spare tires" in promoters [73].

The described data provide a possible new direction for active antiviral design. Up to date, only polymerase inhibitors have been found active against HSV-1, HSV-2 and VZV. However, because of the emergence of resistant strains that may be extremely dangerous especially in transplant and immunocompromised patients [74], new antivirals with a different mechanism of action are highly wished for. We propose that selective anti-IE promoters G4-ligands could hinder the viral cycle at a much earlier stage, preventing the discomfort, the possible neuronal damage, the painful sequelae (specific to VZV) in normal human hosts and the possible life-threatening effects in immunocompromised patients caused by the Alphaherpesviruses.

\section{Materials and Methods}

\subsection{PQS Detection and Evaluation of Conservation}

The complete set of human Alphaherpesvirus genome sequences were downloaded from GenBank. The first analysis was performed with free G4 hunting software (QGRS http://bioinformatics.ramapo. edu/QGRS/index.php and Quadbase http://quadbase.igib.res.in/), using the standard parameters of the two programs (Minimum G-tetrad 2 and 3, Loop length1-7 for GG and 1-12 for GGG). Since Herpesviridae are dsDNA viruses, the presence of PQS was analysed on both genome strands.

\subsection{Oligonucleotides and Cell Lines}

Desalted oligonucleotides were purchased from Invitrogen and from Sigma-Aldrich, Milan, Italy (Table 1, Table 3). U2-OS (ECACC 92022711) were purchased from Sigma Aldrich and maintained in Dulbecco's Modified Eagle's medium (DMEM) (Gibco, Thermo Fisher Scientific, Waltham, MA, USA) supplemented with $10 \%$ heat-in- activated fetal bovine serum (FBS, Gibco, Thermo Fisher Scientific, Waltham, MA, USA). Cells were grown in a humidified incubator maintained at $37^{\circ} \mathrm{C}$ with $5 \% \mathrm{CO}_{2}$.

\subsection{Circular Dichroism Spectroscopy}

DNA oligonucleotides were diluted to a final concentration $(4 \mu \mathrm{M})$ in phosphate buffer $(\mathrm{PB}, 20$ $\mathrm{mM}, \mathrm{pH} 7.4$ ) and $\mathrm{KCl} 70 \mathrm{mM}$. All samples were annealed at $95^{\circ} \mathrm{C}$ for $5 \mathrm{~min}$ and gradually cooled to room temperature. The G4-ligand Braco-19 (B19, ENDOTHERM, Saarbruecken, Germany) was added from stock at final concentration of $16 \mu \mathrm{M}$. CD spectra were recorded on a Chirascan-Plus (Applied Photophysics, Leatherhead, UK) equipped with a Peltier temperature controller using a quartz cell of 5 $\mathrm{mm}$ optical path length, over a wavelength range of 230-320 nm. For the determination of $\mathrm{T}_{\mathrm{m}}$, spectra were recorded over a temperature range of $20-90^{\circ} \mathrm{C}$, with temperature increase of $5{ }^{\circ} \mathrm{C}$. The reported spectra are baseline-corrected for signal contributions due to the buffer. Observed ellipticities were converted to mean residue ellipticity $(\theta)=\operatorname{deg} \times \mathrm{cm}^{2} \times \mathrm{dmol}^{-1}$ (mol ellip). $\mathrm{T}_{\mathrm{m}}$ values were calculated according to the van't Hoff equation, applied for a two-state transition from a folded to unfolded state, assuming that the heat capacity of the folded and unfolded states are equal [75]. 


\subsection{Taq Polymerase Stop Assay}

Taq polymerase stop assay was carried out as previously described [23]. Briefly, the $5^{\prime}$-end labelled primer was annealed to its template (Table S1) in lithium cacodylate buffer in the presence or absence of $\mathrm{KCl}(50-150 \mathrm{mM})$ and by heating at $95^{\circ} \mathrm{C}$ for $5 \mathrm{~min}$ and gradually cooling to room temperature. Where specified, samples were incubated with $1 \mu \mathrm{M}$ B19 for $24 \mathrm{~h}$ after the annealing step. Primer extension was conducted with $2 \mathrm{U}$ of AmpliTaq Gold DNA polymerase (Applied Biosystem, Carlsbad, California, USA) at $47^{\circ} \mathrm{C}$ for $30 \mathrm{~min}$. Reactions were stopped by ethanol precipitation, primer extension products were separated on a $16 \%$ denaturing gel, and finally visualized by phosphorimaging (Typhoon FLA 9000).

\subsection{Plasmids Construction}

The ICP0 and ICP27 promoter regions were amplified by PCR on the HSV-1 genome (GU734771.1) extracted from U2-OS infected cells. The promoter amplicons were subcloned into pGL4.10-Luc2 (Promega) within XhoI and HindIII sites. The resulting pGL4.10-ICP0 and pGL4.10-ICP27 vectors contained the sequenced regions corresponding to nts 1551-2261 (ICP0) and nts 113451-113734 (ICP27) in the HSV-1 reference genome (NC_001806.2), fused to the luciferase-coding region.

\subsection{Reporter Assays}

Vectors pGL4.10-ICP0 and pGL4.10-ICP27 (150 ng each) were transfected in $1.2 \times 10^{5}$ U2-OS cells per well onto 12-well plates, using Lipo3000 transfection reagent (Invitrogen, Life Technologies Italia, Monza, Italy). B19 was added to the cell medium $1 \mathrm{~h}$ after transfection at increasing concentrations (5-20 $\mu \mathrm{M})$, to avoid interference, if any, with transfection. Expression of firefly luciferase was determined 24 $\mathrm{h}$ after transfection using the Britelite plus Reporter Gene Assay System (PerkinElmer Inc., Milan, Italy) at a Victor X2 multilabel plate reader (PerkinElmer Inc., Milan, Italy), according to the manufacturer's instructions. Cells were lysed in $0.1 \%$ Triton-X100-PBS and protein concentration was determined by BCA assay (Thermo Scientific Pierce, Monza, Italy). Luciferase signals were subsequently normalized to total protein content, according to the manufacturer's protocol (http://ita.promega.com/ /pdf/resources/ pubhub/cellnotes/normalizing-genetic-reporter-assays/). Each assay was performed in duplicate and each set of experiments was repeated at least three times.

\subsection{Cellular Cytotoxicity}

Cytotoxic effects were determined by MTT assay. U-2 OS cells were grown and maintained according to manufacturer's instructions (https://www.lgcstandards-atcc.org). Cells were plated into 96-microwell plates to a final volume of $100 \mu \mathrm{L}$ and allowed an overnight period for attachment. The following day, the tested compound (B19) was added to each well and tested in triplicate. Control cells were treated in the exact same conditions. Cell survival was evaluated by MTT assay, $24 \mathrm{~h}$ after treatment: $10 \mu \mathrm{L}$ of freshly dissolved solution of MTT ( $5 \mathrm{mg} / \mathrm{mL}$ in PBS) were added to each well, and after $4 \mathrm{~h}$ of incubation, MTT crystals were solubilized in solubilization solution (10\% sodium dodecyl sulphate (SDS) and $0.01 \mathrm{M} \mathrm{HCl}$ ). After overnight incubation at $37^{\circ} \mathrm{C}$, absorbance was read at $540 \mathrm{~nm}$. Data were expressed as mean values of at least three individual experiments conducted in triplicate. The percentage of cell survival was calculated as follows: cell survival $=($ Awell - Ablank $) /($ Acontrol Ablank $) \times 100$, where blank denotes the medium without cells. Each experiment was repeated at least three times.

\section{Conclusions}

The work presented here provides for the first time a comprehensive analysis on the presence of G4s in the IE promoter regions of the three Alphaherpesviruses that infect humans. In these viruses, regulation of gene expression has been largely debated in the last decades but clear data are still lacking. Thus, the fact that in all Alphaherpesviruses the promoters of all genes involved in the first steps 
of infection and in the control of expression of the later genes contain 100\% conserved G4 forming regions is a potent indication of their significance. Our data broaden the boosting recognition of G4s as molecular switches of gene expression at the viral level [24]. The in-depth understanding of the role of G4s at the viral promoter level will likely allow unravelling the mechanisms that regulate Alphaherpesviruses infection and latency in the human nervous system, with the subsequent possibility to design innovative drugs to manage the infection of some of the most widespread latency-associated human pathogens.

Supplementary Materials: The following are available online, Figure S1: CD thermal unfolding spectra, CD thermal unfolding fitting and TDS of Alphaherpesvirus IE promoter G4 sequences, Table S1: Oligonucleotides used in the Taq polymerase stop assay.

Author Contributions: Conceptualization, I.F. and S.N.R.; methodology, I.F. and M.N.; validation, I.F., M.N. and S.N.R.; formal analysis, I.F. and S.N.R.; investigation, I.F. and M.N.; data curation, I.F. and M.N.; funding acquisition, S.N.R.; writing—original draft preparation, I.F.; writing—review and editing, S.N.R.

Funding: This research was funded by the European Research Council grant number (ERC Consolidator 615879) and by the DMM, University of Padua (PRID RICH-SID18_01).

Conflicts of Interest: The authors declare no conflict of interest.

\section{References}

1. Cutter, A.R.; Hayes, J.J. A brief review of nucleosome structure. FEBS Lett. 2015, 589, 2914-2922. [CrossRef] [PubMed]

2. Burge, S.; Parkinson, G.N.; Hazel, P.; Todd, A.K.; Neidle, S. Quadruplex DNA: Sequence, topology and structure. Nucleic Acids Res. 2006, 34, 5402-5415. [CrossRef] [PubMed]

3. Bochman, M.L.; Paeschke, K.; Zakian, V.A. DNA secondary structures: Stability and function of G-quadruplex structures. Nat. Rev. Genet. 2012, 13, 770-780. [CrossRef] [PubMed]

4. Bacolla, A.; Wang, G.; Vasquez, K.M. New Perspectives on DNA and RNA Triplexes As Effectors of Biological Activity. PLoS Genet. 2015, 11, e1005696. [CrossRef] [PubMed]

5. Harkness, R.W.; Mittermaier, A.K. G-quadruplex dynamics. Biochim. Biophys. Acta-Proteins Proteomics 2017, 1865, 1544-1554. [CrossRef] [PubMed]

6. Huppert, J.L. Four-stranded nucleic acids: Structure, function and targeting of G-quadruplexes. Chem. Soc. Rev. 2008, 37, 1375-1384. [CrossRef] [PubMed]

7. del Villar-Guerra, R.; Trent, J.O.; Chaires, J.B. G-Quadruplex Secondary Structure Obtained from Circular Dichroism Spectroscopy. Angew. Chemie Int. Ed. 2018, 57, 7171-7175. [CrossRef]

8. Mergny, J.L.; Phan, A.T.; Lacroix, L. Following G-quartet formation by UV-spectroscopy. FEBS Lett. 1998, 435, 74-78. [CrossRef]

9. Han, H.; Hurley, L.H.; Salazar, M. A DNA polymerase stop assay for G-quadruplex-interactive compounds. Nucleic Acids Res. 1999, 27, 537-542. [CrossRef]

10. Scalabrin, M.; Palumbo, M.; Richter, S.N. Highly Improved Electrospray Ionization-Mass Spectrometry Detection of G-Quadruplex-Folded Oligonucleotides and Their Complexes with Small Molecules. Anal. Chem. 2017, 89, 8632-8637. [CrossRef]

11. Tretyakova, N.; Villalta, P.W.; Kotapati, S. Mass spectrometry of structurally modified DNA. Chem. Rev. 2013, 113, 2395-2436. [CrossRef] [PubMed]

12. Manna, S.; Sarkar, D.; Srivatsan, S.G. A Dual-App Nucleoside Probe Provides Structural Insights into the Human Telomeric Overhang in Live Cells. J. Am. Chem. Soc. 2018, 140, 12622-12633. [CrossRef] [PubMed]

13. Bao, H.-L.; Liu, H.; Xu, Y. Hybrid-type and two-tetrad antiparallel telomere DNA G-quadruplex structures in living human cells. Nucleic Acids Res. 2019, 47, 4940-4947. [CrossRef] [PubMed]

14. Fay, M.M.; Lyons, S.M.; Ivanov, P. RNA G-Quadruplexes in Biology: Principles and Molecular Mechanisms. J. Mol. Biol. 2017, 429, 2127-2147. [CrossRef] [PubMed]

15. Rhodes, D.; Lipps, H.J. G-quadruplexes and their regulatory roles in biology. Nucleic Acids Res. 2015, 43, 8627-8637. [CrossRef] [PubMed]

16. Cammas, A.; Millevoi, S. RNA G-quadruplexes: Emerging mechanisms in disease. Nucleic Acids Res. 2016, 45, gkw1280. [CrossRef] [PubMed] 
17. Artusi, S.; Nadai, M.; Perrone, R.; Biasolo, M.A.; Palù, G.; Flamand, L.; Calistri, A.; Richter, S.N. The Herpes Simplex Virus-1 genome contains multiple clusters of repeated G-quadruplex: Implications for the antiviral activity of a G-quadruplex ligand. Antiviral Res. 2015, 118, 123-131. [CrossRef]

18. Ravichandran, S.; Kim, Y.-E.; Bansal, V.; Ghosh, A.; Hur, J.; Subramani, V.K.; Pradhan, S.; Lee, M.K.; Kim, K.K.; Ahn, J.-H. Genome-wide analysis of regulatory G-quadruplexes affecting gene expression in human cytomegalovirus. PLoS Pathog. 2018, 14, e1007334. [CrossRef]

19. Norseen, J.; Johnson, F.B.; Lieberman, P.M. Role for G-quadruplex RNA binding by Epstein-Barr virus nuclear antigen 1 in DNA replication and metaphase chromosome attachment. J. Virol. 2009, 83, 10336-10346. [CrossRef]

20. Harris, L.M.; Monsell, K.R.; Noulin, F.; Famodimu, M.T.; Smargiasso, N.; Damblon, C.; Horrocks, P.; Merrick, C.J. G-Quadruplex DNA Motifs in the Malaria Parasite Plasmodium falciparum and Their Potential as Novel Antimalarial Drug Targets. Antimicrob. Agents Chemother. 2018, 62, e01828-17. [CrossRef]

21. Fleming, A.M.; Ding, Y.; Alenko, A.; Burrows, C.J. Zika Virus Genomic RNA Possesses Conserved G-Quadruplexes Characteristic of the Flaviviridae Family. ACS Infect. Dis. 2016, 2, 674-681. [CrossRef] [PubMed]

22. Harris, L.M.; Merrick, C.J. G-quadruplexes in pathogens: A common route to virulence control? PLoS Pathog. 2015, 11, e1004562. [CrossRef] [PubMed]

23. Perrone, R.; Nadai, M.; Frasson, I.; Poe, J.A.; Butovskaya, E.; Smithgall, T.E.; Palumbo, M.; Palù, G.; Richter, S.N. A Dynamic G-Quadruplex Region Regulates the HIV-1 Long Terminal Repeat Promoter. J. Med. Chem. 2013, 56, 6521-6530. [CrossRef] [PubMed]

24. Ruggiero, E.; Richter, S.N. G-quadruplexes and G-quadruplex ligands: Targets and tools in antiviral therapy. Nucleic Acids Res. 2018, 46, 3270-3283. [CrossRef] [PubMed]

25. Bhartiya, D.; Chawla, V.; Ghosh, S.; Shankar, R.; Kumar, N. Genome-wide regulatory dynamics of G-quadruplexes in human malaria parasite Plasmodium falciparum. Genomics 2016, 108, 224-231. [CrossRef] [PubMed]

26. Madireddy, A.; Purushothaman, P.; Loosbroock, C.P.; Robertson, E.S.; Schildkraut, C.L.; Verma, S.C. G-quadruplex-interacting compounds alter latent DNA replication and episomal persistence of KSHV. Nucleic Acids Res. 2016, 44, 3675-3694. [CrossRef] [PubMed]

27. Artusi, S.; Perrone, R.; Lago, S.; Raffa, P.; Di Iorio, E.; Palù, G.; Richter, S.N. Visualization of DNA G-quadruplexes in herpes simplex virus 1-infected cells. Nucleic Acids Res. 2016, 44, 10343-10353. [CrossRef]

28. Roizman, B.; Baines, J. The diversity and unity of herpesviridae. Comp. Immunol. Microbiol. Infect. Dis. 1991, 14, 63-79. [CrossRef]

29. Honess, R.W.; Roizman, B. Regulation of herpesvirus macromolecular synthesis: Sequential transition of polypeptide synthesis requires functional viral polypeptides. Proc. Natl. Acad. Sci. USA 1975, 72, 1276-1280. [CrossRef]

30. Honess, R.W.; Roizman, B. Regulation of herpesvirus macromolecular synthesis. I. Cascade regulation of the synthesis of three groups of viral proteins. J. Virol. 1974, 14, 8-19.

31. Babb, R.; Huang, C.C.; Aufiero, D.J.; Herr, W. DNA recognition by the herpes simplex virus transactivator VP16: A novel DNA-binding structure. Mol. Cell. Biol. 2001, 21, 4700-4712. [CrossRef] [PubMed]

32. Callegaro, S.; Perrone, R.; Scalabrin, M.; Doria, F.; Palù, G.; Richter, S.N. A core extended naphtalene diimide G-quadruplex ligand potently inhibits herpes simplex virus 1 replication. Sci. Rep. 2017, 7, 2341. [CrossRef] [PubMed]

33. Lavezzo, E.; Berselli, M.; Frasson, I.; Perrone, R.; Palù, G.; Brazzale, A.R.; Richter, S.N.; Toppo, S. G-quadruplex forming sequences in the genome of all known human viruses: A comprehensive guide. PLoS Comput. Biol. 2018, 14, e1006675. [CrossRef] [PubMed]

34. Pesola, J.M.; Zhu, J.; Knipe, D.M.; Coen, D.M. Herpes simplex virus 1 immediate-early and early gene expression during reactivation from latency under conditions that prevent infectious virus production. $J$. Virol. 2005, 79, 14516-14525. [CrossRef] [PubMed]

35. Bedrat, A.; Lacroix, L.; Mergny, J.-L. Re-evaluation of G-quadruplex propensity with G4Hunter. Nucleic Acids Res. 2016, 44, 1746-1759. [CrossRef] [PubMed]

36. Rice, S.A.; Knipe, D.M. Gene-specific transactivation by herpes simplex virus type 1 alpha protein ICP27. J. Virol. 1988, 62, 3814-3823. [PubMed] 
37. McGeoch, D.J.; Dolan, A.; Donald, S.; Rixon, F.J. Sequence determination and genetic content of the short unique region in the genome of herpes simplex virus type 1. J. Mol. Biol. 1985, 181, 1-13. [CrossRef]

38. Dauber, B.; Saffran, H.A.; Smiley, J.R. The herpes simplex virus 1 virion host shutoff protein enhances translation of viral late mRNAs by preventing mRNA overload. J. Virol. 2014, 88, 9624-9632. [CrossRef]

39. Lee, J.S.; Raja, P.; Knipe, D.M. Herpesviral ICP0 Protein Promotes Two Waves of Heterochromatin Removal on an Early Viral Promoter during Lytic Infection. MBio 2016, 7, e02007-15. [CrossRef]

40. Kuddus, R.; Gu, B.; DeLuca, N.A. Relationship between TATA-binding protein and herpes simplex virus type 1 ICP4 DNA-binding sites in complex formation and repression of transcription. J. Virol. 1995, 69, 5568-5575.

41. Chan, C.-Y.; Umar, M.I.; Kwok, C.K. Spectroscopic analysis reveals the effect of a single nucleotide bulge on G-quadruplex structures. Chem. Commun. (Camb.) 2019, 55, 2616-2619. [CrossRef] [PubMed]

42. Dolan, A.; Jamieson, F.E.; Cunningham, C.; Barnett, B.C.; McGeoch, D.J. The genome sequence of herpes simplex virus type 2. J. Virol. 1998, 72, 2010-2021. [PubMed]

43. Cohen, J.I. The Varicella-Zoster Virus Genome; Springer: Berlin/Heidelberg, Germany, 2010; pp. 1-14.

44. Jones, J.O.; Sommer, M.; Stamatis, S.; Arvin, A.M. Mutational Analysis of the Varicella-Zoster Virus ORF62/63 Intergenic Region. J. Virol. 2006, 80, 3116-3121. [CrossRef] [PubMed]

45. Norberg, P.; Tyler, S.; Severini, A.; Whitley, R.; Liljeqvist, J.-Å.; Bergström, T. A genome-wide comparative evolutionary analysis of herpes simplex virus type 1 and varicella zoster virus. PLOS ONE 2011, 6, e22527. [CrossRef] [PubMed]

46. Szpara, M.L.; Gatherer, D.; Ochoa, A.; Greenbaum, B.; Dolan, A.; Bowden, R.J.; Enquist, L.W.; Legendre, M.; Davison, A.J. Evolution and diversity in human herpes simplex virus genomes. J. Virol. 2014, 88, 1209-1227. [CrossRef] [PubMed]

47. Reinhold, W.C.; Straus, S.E.; Ostrove, J.M. Directionality and further mapping of varicella zoster virus transcripts. Virus Res. 1988, 9, 249-261. [CrossRef]

48. Che, X.; Zerboni, L.; Sommer, M.H.; Arvin, A.M. Varicella-zoster virus open reading frame 10 is a virulence determinant in skin cells but not in T cells in vivo. J. Virol. 2006, 80, 3238-3248. [CrossRef] [PubMed]

49. Moriuchi, M.; Moriuchi, H.; Straus, S.E.; Cohen, J.I. Varicella-Zoster Virus (VZV) Virion-Associated Transactivator Open Reading Frame 62 Protein Enhances the Infectivity of VZV DNA. Virology 1994, 200, 297-300. [CrossRef]

50. Moriuchi, H.; Moriuchi, M.; Straus, S.E.; Cohen, J.I. Varicella-zoster virus open reading frame 10 protein, the herpes simplex virus VP16 homolog, transactivates herpesvirus immediate-early gene promoters. J. Virol. 1993, 67, 2739-2746.

51. Zhou, J.; Rosu, F.; Amrane, S.; Korkut, D.N.; Gabelica, V.; Mergny, J.L. Assembly of chemically modified G-rich sequences into tetramolecular DNA G-quadruplexes and higher order structures. Methods 2014, 67, 159-168. [CrossRef]

52. Harrison, R.J.; Cuesta, J.; Chessari, G.; Martin, A.R.; Sanji, K.B.; Anthony, P.R.; Morrell, J.; Sharon, M.G.; Christopher, M.I.; Farial, A.T.; et al. Trisubstituted Acridine Derivatives as Potent and Selective Telomerase Inhibitors. J. Med. Chem. 2003, 46, 4463-4476. [CrossRef] [PubMed]

53. Mergny, J.-L. Thermal difference spectra: A specific signature for nucleic acid structures. Nucleic Acids Res. 2005, 33, e138. [CrossRef] [PubMed]

54. Smith, M.C.; Boutell, C.; Davido, D.J. HSV-1 ICP0: Paving the way for viral replication. Future Virol. 2011, 6, 421-429. [CrossRef] [PubMed]

55. Sedlackova, L.; Perkins, K.D.; Lengyel, J.; Strain, A.K.; van Santen, V.L.; Rice, S.A. Herpes simplex virus type $1 \mathrm{ICP} 27$ regulates expression of a variant, secreted form of glycoprotein $\mathrm{C}$ by an intron retention mechanism. J. Virol. 2008, 82, 7443-7455. [CrossRef] [PubMed]

56. Suk, H.; Knipe, D.M. Proteomic analysis of the herpes simplex virus 1 virion protein 16 transactivator protein in infected cells. Proteomics 2015, 15, 1957-1967. [PubMed]

57. De Nicola, B.; Lech, C.J.; Heddi, B.; Regmi, S.; Frasson, I.; Perrone, R.; Richter, S.N.; Phan, A.T. Structure and possible function of a G-quadruplex in the long terminal repeat of the proviral HIV-1 genome. Nucleic Acids Res. 2016, 44, 6442-6451. [CrossRef]

58. Perrone, R.; Doria, F.; Butovskaya, E.; Frasson, I.; Botti, S.; Scalabrin, M.; Lago, S.; Grande, V.; Nadai, M.; Freccero, M.; et al. Synthesis, Binding and Antiviral Properties of Potent Core-Extended Naphthalene Diimides Targeting the HIV-1 Long Terminal Repeat Promoter G-Quadruplexes. J. Med. Chem. 2015, 58, 9639-9652. [CrossRef] 
59. Perrone, R.; Butovskaya, E.; Daelemans, D.; Palu, G.; Pannecouque, C.; Richter, S.N. Anti-HIV-1 activity of the G-quadruplex ligand BRACO-19. J. Antimicrob. Chemother. 2014, 69, 3248-3258. [CrossRef]

60. Harkness, J.M.; Kader, M.; DeLuca, N.A. Transcription of the herpes simplex virus 1 genome during productive and quiescent infection of neuronal and nonneuronal cells. J. Virol. 2014, 88, 6847-6861. [CrossRef]

61. Lopergolo, A.; Perrone, R.; Tortoreto, M.; Doria, F.; Beretta, G.L.; Zuco, V.; Freccero, M.; Borrello, M.G.; Lanzi, C.; Richter, S.N.; et al. Targeting of RET oncogene by naphthalene diimide-mediated gene promoter G-quadruplex stabilization exerts anti-tumor activity in oncogene-addicted human medullary thyroid cancer. Oncotarget 2016, 7, 49649-49663. [CrossRef]

62. Tong, X.; Lan, W.; Zhang, X.; Wu, H.; Liu, M.; Cao, C. Solution structure of all parallel G-quadruplex formed by the oncogene RET promoter sequence. Nucleic Acids Res. 2011, 39, 6753-6763. [CrossRef] [PubMed]

63. Lerner, L.K.; Sale, J.E. Replication of G Quadruplex DNA. Genes (Basel) 2019, 10. [CrossRef] [PubMed]

64. Tlučková, K.; Marušič, M.; Tóthová, P.; Bauer, L.; Šket, P.; Plavec, J.; Viglasky, V. Human Papillomavirus G-Quadruplexes. Biochemistry 2013, 52, 7207-7216. [CrossRef] [PubMed]

65. Palumbo, S.L.; Ebbinghaus, S.W.; Hurley, L.H. Formation of a unique end-to-end stacked pair of G-quadruplexes in the hTERT core promoter with implications for inhibition of telomerase by G-quadruplex-interactive ligands. J. Am. Chem. Soc. 2009, 131, 10878-10891. [CrossRef] [PubMed]

66. Sun, D.; Liu, W.-J.; Guo, K.; Rusche, J.J.; Ebbinghaus, S.; Gokhale, V.; Hurley, L.H. The proximal promoter region of the human vascular endothelial growth factor gene has a G-quadruplex structure that can be targeted by G-quadruplex-interactive agents. Mol. Cancer Ther. 2008, 7, 880-889. [CrossRef] [PubMed]

67. Rigo, R.; Sissi, C. Characterization of G4-G4 Crosstalk in the c-KIT Promoter Region. Biochemistry 2017, 56, 4309-4312. [CrossRef] [PubMed]

68. Summers, B.C.; Leib, D.A. Herpes simplex virus type 1 origins of DNA replication play no role in the regulation of flanking promoters. J. Virol. 2002, 76, 7020-7029. [CrossRef]

69. Zhi, Y.; Sandri-Goldin, R.M. Analysis of the phosphorylation sites of herpes simplex virus type 1 regulatory protein ICP27. J. Virol. 1999, 73, 3246-3257.

70. Smith, I.L.; Hardwicke, M.A.; Sandri-Goldin, R.M. Evidence that the herpes simplex virus immediate early protein ICP27 acts post-transcriptionally during infection to regulate gene expression. Virology 1992, 186, 74-86. [CrossRef]

71. Sandri-Goldin, R.M. The many roles of the highly interactive HSV protein ICP27, a key regulator of infection. Future Microbiol. 2011, 6, 1261-1277. [CrossRef]

72. Sahakyan, A.B.; Chambers, V.S.; Marsico, G.; Santner, T.; Di Antonio, M.; Balasubramanian, S. Machine learning model for sequence-driven DNA G-quadruplex formation. Sci. Rep. 2017, 7, 14535. [CrossRef] [PubMed]

73. Omaga, C.A.; Fleming, A.M.; Burrows, C.J. The Fifth Domain in the G-Quadruplex-Forming Sequence of the Human NEIL3 Promoter Locks DNA Folding in Response to Oxidative Damage. Biochemistry 2018, 57, 2958-2970. [CrossRef] [PubMed]

74. Jiang, Y.-C.; Feng, H.; Lin, Y.-C.; Guo, X.-R. New strategies against drug resistance to herpes simplex virus. Int. J. Oral Sci. 2016, 8, 1-6. [CrossRef] [PubMed]

75. Greenfield, N.J. Using circular dichroism collected as a function of temperature to determine the thermodynamics of protein unfolding and binding interactions. Nat. Protoc. 2006, 1, 2527-2535. [CrossRef] [PubMed]

Sample Availability: Not available. 